\title{
Casus Silesia Superior. Obecny stan i kierunki zagospodarowania kopalni podziemnych w regionie górnośląskim
}

\section{Casus Silesia Superior. Current state and course of development of underground mines in Upper Silesia}

\section{Streszczenie}

Artykuł zawiera prezentację wyników badań nad obecnym stanem i kierunkami zagospodarowania kopalni w regionie Górnego Śląska. Zrealizowane badania objęły kilkadziesiąt miejsc związanych z eksploatacją węgla kamiennego. Autor skupił się na zespołach szybowych kopalni podziemnych. Przedstawiono ich rozmieszczenie oraz poddano analizie pod kątem istotnych cech. Scharakteryzowano procesy związane z przemysłową działalnością kopalni, a także ich likwidacją oraz ewentualną adaptacją do nowych funkcji.

Słowa kluczowe: przestrzeń górnicza, obiekty i tereny pogórnicze, zagospodarowanie, adaptacja, rewitalizacja, górnictwo węgla kamiennego, kopalnia podziemna

\begin{abstract}
This paper is a presentation of the findings on the current state and course of development of mines in the area of the Upper Silesia. The study covered several dozen sites associated with procurement of coal. The author focused on the shaft complexes of underground mines. Their distribution has been presented and subjected to analysis in terms of essential characteristics. Processes associated with the industrial activity of mine, its liquidation and possible adaptive reuse were characterised.
\end{abstract}

Keywords: mining space, post-mining buildings and areas, development, adaptation, revitalisation, coal mining, underground mine 


\section{WSTĘP}

Europejskie górnictwo węglowe osiągnęło szczyt rozwoju w latach 60. i 70. XX wieku. Na fali powojennej industrializacji kontynentu powstały liczne kopalnie podziemne, działające głównie na potrzeby hutnictwa stali i energetyki konwencjonalnej. W większości krajów Europy funkcjonowały zurbanizowane regiony przemysłowe, zdominowane przez kombinaty węglowo-stalowe: Zagłębie Ruhry i Saary w Niemczech, Moselle i Nord-Pas-de-Calais we Francji, holenderska i belgijska Limburgia, część Luksemburga, południowy Yorkshire w Wielkiej Brytanii, północne obszary Hiszpanii czy pogranicze polsko-czeskie z regionem górnośląskim.

Granica podziału pomiędzy zachodnią i wschodnią częścią powojennej Europy była zarazem linią determinującą tempo i charakter przemian regionów górnictwa węglowego. Niespełna dwadzieścia lat po II wojnie światowej w państwach zachodnioeuropejskich pojawiły się symptomy reorientacji gospodarki w kierunku „czystych” technologii. Wobec problemów ekonomicznych, społecznych i środowiskowych kraje zachodnioeuropejskie przystąpiły do likwidacji górnictwa węglowego. Pod koniec ubiegłego stulecia zamknięto kopalnie w krajach Beneluksu, wkrótce potem umarło górnictwo węglowe we Francji. Niemcy zaprzestały dotowania węgla kamiennego w 2018 roku, przesądzając tym samym los dwóch ostatnich czynnych kopalni. Równocześnie w krajach dawnego bloku wschodniego sektor górniczy węgla kamiennego nadal prężnie funkcjonował. W Polsce energetyka konwencjonalna oparta na węglu oraz presja środowisk górniczych jest wciąż pretekstem do wspierania tej branży - pomimo wątpliwego uzasadnienia ekonomicznego oraz ewidentnych szkód dla środowiska. Wydaje się, że hasło „Polska węglem stoi”, ukute niemal pięćdziesiąt lat temu, pozostaje wciąż aktualne i prawdopodobnie polski węgiel kamienny będzie eksploatowany jeszcze przez kilka dekad (Wehnert i in., 2017). Obecnie, na terenie wszystkich krajów UE wciąż funkcjonuje 79 kopalni węgla kamiennego (Alves Dias i in., 2019), eksploatujących surowiec głównie na potrzeby sektora hutniczego i energetyki konwencjonalnej (Jelinek, 2013), z czego aż 18 to kopalnie polskie.

Europejskie regiony górnictwa podziemnego aktualnie przechodzą lub niedawno przeszły głęboką transformację. Przeobrażenia tych obszarów wiążą się zasadniczo z dwoma fazami działalności górniczej oraz procesami zachodzącymi po ustaniu tej działalności (il. 1):

a. czynną eksploatacją węgla kamiennego w kopalniach podziemnych;

b. fazą po zaprzestaniu działalności przemysłowej, obejmującą:

- likwidację kopalni z rekultywacją terenów dotkniętych skutkami eksploatacji;

- ewentualny etap zagospodarowania terenów i obiektów pogórniczych na nowe cele - poprzez ich funkcjonalną adaptację.

Wskazane fazy oraz związane z nimi procesy są typowe dla wszystkich regionów węglowych w Europie. Mogą się jednak charakteryzować odmienną dynamiką, czasem trwania i momentem inicjacji - w zależności od lokalnych uwarunkowań prawnych, ekonomicznych, politycznych i innych. Górny Śląsk odróżnia się od większości obszarów górniczych w Europie 


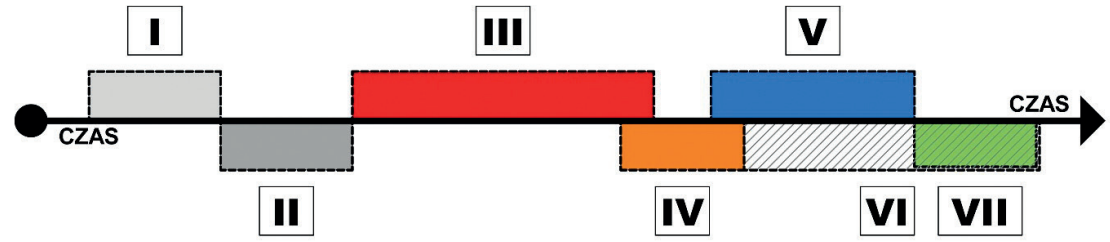

Legenda:

Faza „A":

Etap I - Rozpoznawanie i dokumentowanie złoża surowca.

Etap II - Projektowanie i budowanie kopalni, uzyskiwanie koncesji na wydobycie surowca.

Etap III - Czynna działalność przemysłowa kopalni - wydobywane surowca na zmiennym poziomie.

Faza „B":

Etap IV - Likwidacja zakładu górniczego (proces inicjowany na końcowym etapie fazy III).

Etap V - Adaptacja funkcjonalna kopalni i jej zagospodarowanie do nowych celów (faza opcjonalna).

Etap VI - Brak użytkowania zlikwidowanej kopalni w okresie poprzemysłowym (faza opcjonalna).

Etap VII - Użytkowanie kopalni adaptowanej do nowej funkcji w okresie poprzemysłowym.

\section{1. Typowy schemat funkcjonowania kopalni podziemnej w czasie. Oprac. własne}

Zachodniej, ponieważ nadal pozostaje miejscem intensywnej eksploatacji węgla. Jednocześnie zachodzą w nim wszystkie procesy związane z przekształcaniem kopalni, tj. jej likwidacją oraz ewentualną adaptacją do nowych funkcji.

Niniejsza publikacja zawiera wyniki autorskich badań, których celem było rozpoznanie obecnego stanu działalności oraz kierunków zagospodarowania podziemnych kopalni węgla kamiennego zlokalizowanych na terenie Górnośląskiego Zagłębia Węglowego oraz części Zagłębia Dąbrowskiego, w geograficznym i historycznym regionie Górnego Śląska (łac. Silesia Superior).

\section{CEL, ZAKRES I METODA BADAŃ}

Zasadniczym celem artykułu jest znalezienie odpowiedzi na szereg pytań: W jakim stopniu Górny Śląsk pozostaje czynnym regionem górniczym? Jaki jest obecny stan kopalni węgla kamiennego wyłączonych z eksploatacji surowców? W jakim zakresie górnośląskie kopalnie są wykorzystywane do nowych celów w okresie poprzemysłowym? Wreszcie - na czym polega specyfika Górnego Śląska w odniesieniu do innych europejskich obszarów górnictwa węglowego, a także jakie są podobieństwa pomiędzy tymi regionami? Naukową podstawę rozważań stanowią autorskie badania terenowe, zrealizowane w trakcie sześciu wyjazdów studialnych (październik 2012-sierpień 2018). Przeprowadzono analizę kilkudziesięciu miejsc związanych z podziemną eksploatacją węgla kamiennego, koncentrując się na zespołach szybowych czynnych i zlikwidowanych zakładów górniczych. Były to ${ }^{1}$

Zespoły szybowe przypisano do miast górnośląskich, kierując się kryterium administracyjnym, zastrzegając,
że niektóre z nich stanowią integralną częśc większych zakładów górniczych, których siedziby mogą znajdo- 
- w Bytomiu: kopalnia „Rozbark” i „Szombierki”;

- w Chorzowie: kopalnia „Barbara” i „Polska” (szyb „Prezydent”);

- w Chudowie: kopalnia „Budryk” (szyb „Chudów VI”);

- w Czeladzi: kopalnia "Saturn”;

- w Czerwionce-Leszczynie: kopalnia „Dębieńsko”;

- w Gliwicach: kopalnia „Gliwice” i „Sośnica”;

- w Katowicach: kopalnia „Gottwald”, „Katowice”, „Kleofas”, „Murcki-Staszic”, nadszybia „Pułaski” i „Wilson” kopalni „Wieczorek”, kopalnia „Wujek”;

- w Knurowie: kopalnia „Knurów-Szczygłowice” (szyby I-III, V, „Foch I-II”);

- w Mysłowicach: kopalnia „Mysłowice-Wesoła”, w tym szyb „Bończyk”;

- w Ornontowicach: kopalnia „Budryk”;

- w Piekarach Śląskich: kopalnia „Andaluzja” i „Bobrek-Piekary”;

- w Rudzie Śląskiej: kopalnia „Bielszowice”, „Pokój”, „Ruda” i „Wirek”;

- w Rybniku: nadszybia „Głowacki” i „Kościuszko” kopalni „Ignacy”;

- w Siemianowicach Śląskich: kopalnia „Siemianowice” i szyb „Krystyn” kopalni „Michał”;

- w Świętochłowicach: nadszybia „I" i „II" kopalni „Polska”

- w Tychach: nadszybie „Czułów II" kopalni „Boże Dary”;

- wZabrzu: kopalnia „Guido” i sztolnia „Królowa Luiza” oraz szyb „Maciej” kopalni „Concordia”. Istotą publikacji jest prezentacja wyników zrealizowanych badań, tj. przedstawienie obecnego stanu funkcjonalnego badanych kopalni oraz sposobu i zakresu zagospodarowania zakładów górniczych wyłączonych z działalności przemysłowej. Szczegółowej analizie poddano łącznie 38 zespołów szybowych należących do niemal wszystkich kopalni podziemnych w regionie (il. 2). Duża liczba oraz zróżnicowanie badanych kopalni pozwala na rozpoznanie zjawisk i procesów charakterystycznych dla całego regionu Górnego Śląska. Wytypowania obiektów do badań terenowych dokonano na podstawie przeglądu literatury przedmiotu (np. Frużyński, 2012), a także szczegółowej analizy map topograficznych Górnego Śląska w skali 1 : 50 000, pozwalających na skuteczną identyfikację reprezentatywnej większości miejsc dawnej i czynnej eksploatacji węgla kamiennego w badanym obszarze.

W klasyfikacji obecnego stanu funkcjonowania analizowanych kopalni oraz ewentualnego kierunku ich wtórnego wykorzystania zastosowano autorską metodę, która objęła:

- identyfikację obecnego stanu działalności górniczej kopalni (lub jej części) - rozróżnienie kopalni aktywnych i nieczynnych w odniesieniu do eksploatacji surowca;

- w przypadku kopalni wyłączonych z eksploatacji - określenie fazy tego wyłączenia, tj. wskazanie obiektów całkowicie zlikwidowanych oraz pozostających w fazie likwidacji;

- w stosunku do obiektów trwale zlikwidowanych - wskazanie kopalni zagospodarowanych na nowe funkcji oraz pozostawionych jako nieużytki bez nadania nowej funkcji.

wać się w odległych miejscach regionu. Ze względu na trwające przekształcenia organizacyjne i własnościowe górnośląskich kopalni węgla ich nazewnictwo podane w spisie może nie być zgodne ze stanem obecnym. 


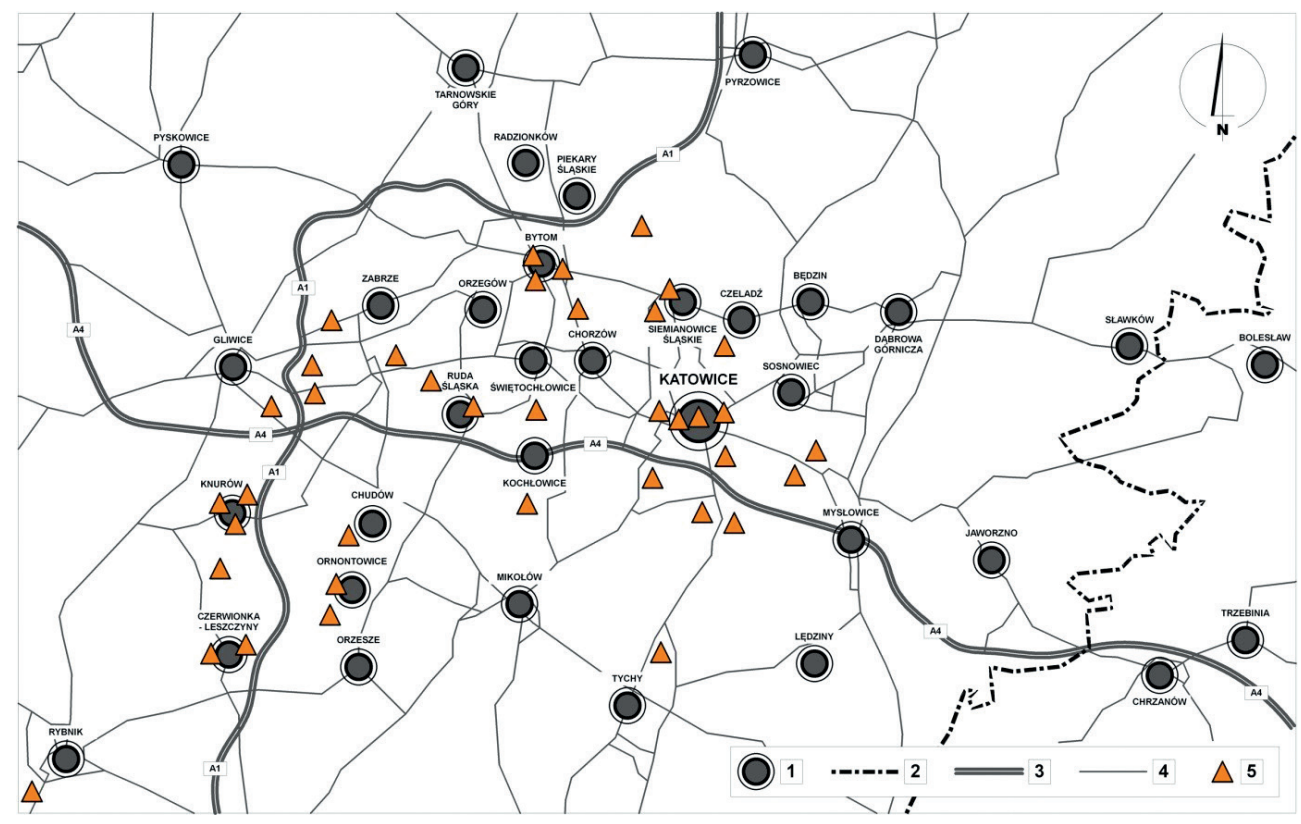

II. 2. Usytuowanie kopalni podziemnych objętych badaniami terenowymi w regionie górnośląskim: 1 - ośrodki miejskie; 2 - granica województwa śląskiego i małopolskiego; 3 - autostrady; 4 - pozostałe ważniejsze drogi; 5 - obiekty objęte autorskimi badaniami terenowymi. Oprac. własne na podstawie mapy topograficznej

Ponadto rozpatrując formę poprzemysłowego zagospodarowania kopalni, wyróżniono dwa zasadnicze kierunki ich adaptacji: „komercyjny” i „kulturowy”, wskazując jako kryterium podziału generalne podejście do zachowanego dziedzictwa kulturowego - co jest kluczowe dla sfery przestrzennej i krajobrazowej, a także dla szeroko pojętej atrakcyjności Górnego Śląska. Przyjęta metoda wydaje się odpowiednia dla zakresu przeprowadzonych badań, w szczególności uwzględnia charakter analizowanych obiektów, którymi są wyłącznie zespoły szybowe kopalni podziemnych. Uznano jednocześnie, że metody analizy funkcjonalnej przedstawione w dostępnych publikacjach naukowych są trudne do implementacji w przeprowadzonych badaniach kopalni podziemnych Górnego Śląska (Kaźmierczak i in., 2017), ponieważ odnoszą się głównie do elementów związanych z eksploatacją odkrywkową oraz rozległych terenów pogórniczych towarzyszących kopalniom podziemnym, np. zwałowisk, oraz obszarów dotkniętych szkodami górniczymi (Kuter, 2013). Ponadto metody te nie uwzględniają związku pomiędzy kierunkiem funkcjonalnej przebudowy obszarów pogórniczych z ich wartością kulturową.

W syntezie wyników badań dokonano zbiorczej charakterystyki analizowanych obiektów (tab. 1) z uwzględnieniem takich cech jak: aktualny stan działalności, czas i okres funkcjonowania jako obiekt przemysłowy, obecny stan zachowania wyrobisk górniczych i infrastruktury 
naziemnej, jak również kierunek zagospodarowania i forma użytkowania w okresie pogórniczym. Dane uzyskane w toku przeprowadzonych analiz zestawiono w ujęciu ilościowym (tab. 2). W części wnioskowej odniesiono się do przeobrażeń innych obszarów podziemnego górnictwa węglowego, badanych i opisywanych wcześniej przez autora, tj. Zagłębia Saary w Niemczech, departamentu Moselle (Langer, 2017) i Nord-Pas-de-Calais we Francji oraz w belgijskiej części Limburgii (Langer, 2019).

\section{SPECYFIKA GÓRNEGO ŚLĄSKA W ODNIESIENIU DO OBECNEGO STANU POLSKIEGO GÓRNICTWA WĘGLOWEGO}

W odróżnieniu od większości państw zachodnioeuropejskich gospodarka Polski w znacznym stopniu nadal opiera się na węglu kamiennym. Surowiec ten jest wykorzystywany jako paliwo (węgiel energetyczny) oraz w hutnictwie stali (węgiel koksujący). Wydobycie tego surowca w Polsce jest nadal relatywnie duże. W 2016 roku wyniosło ono około $70 \mathrm{mln}$. ton, co stanowiło 70\% łącznej produkcji węgla kamiennego we wszystkich krajach Unii Europejskiej (Ministerstwo Gospodarki, 2018). Według danych statystycznych w tym samym roku na potrzeby polskiego sektora energetycznego wykorzystano prawie $60 \%$ ogólnej ilości węgla kamiennego pozyskanego w kraju lub importowanego z zagranicy² (Główny Urząd Statystyczny, 2017; Gawlik i in., 2014). Wbrew tendencjom obserwowanym w krajach rozwiniętych węgiel kamienny jest wskazywany jako podstawowy nośnik energii produkowanej w Polsce w realnej perspektywie nawet do 2050 roku (Gawlik, 2013; Kaliski i in., 2014) - bez względu na rosnące koszty wydobycia oraz wyzwania związane z ochroną środowiska i klimatu. Pomimo deklaracji zwiększenia produkcji energii ze źródeł odnawialnych oraz trwającej dyskusji nad energetyką jądrową, inwestycje w polski sektor energetyczny skupiają się na możliwie szybkiej modernizacji i rozbudowie elektrowni konwencjonalnych, w tym zasilanych węglem kamiennym (Gawlik, 2013). Można przypuszczać, że eksploatacja polskiego węgla metodą podziemną może być jeszcze długo kontynuowana, pomimo przewidywanej przez ekspertów redukcji wielkości wydobycia (Stala-Szlugaj i in., 2017). Nie należy się zatem spodziewać rychłej likwidacji wszystkich kopalni pozyskujących rodzimy węgiel kamienny.

Na terenie Polski istnieją aktualnie tylko dwa regiony czynnej eksploatacji węgla kamiennego - górnośląski oraz lubelski. Istotne jest, że zdecydowana większość węgla kamiennego pozyskiwanego w Polsce pochodzi z Górnego Śląska - w 2015 roku było to aż 90\% (Probierz, 2015). Obecnie w regionie górnośląskim operuje kilka niezależnych spółek prowadzących

\footnotetext{
Należy zastrzec, że w całkowitym bilansie węgla energetycznego zużywanego w Polsce duży udział ma surowiec importowany - przede wszystkim z Rosji, ale także ze Stanów Zjednoczonych, Czech, Ukrainy, Kolumbii i Australii (Stala-Szlugaj, 2014). Dane Ministerstwa Energii wskazują, że w 2018 roku Polska sprowadziła z zagranicy niemal $20 \mathrm{mln}$ ton węgla, co stanowi prawie 1/3 ogólnej ilości zużywanego surowca.
} 
czynne wydobycie węgla i zrzeszających poszczególne kopalnie 3 (Chmielewska, 2010). Struktura własnościowa i organizacyjna produkcji węgla na Górnym Śląsku zmienia się jednak dosyć często. Jest to niewątpliwie sygnałem transformacji, jaką od kilku dekad przechodzi polskie górnictwo węglowe (Podgórska-Jurkowska, 1994). Niezależnie od dokonujących się przemian Górnośląskie Zagłębie Węglowe jest jednym z ostatnich regionów europejskich, w którym wciąż wydobywany jest węgiel kamienny. Przez jakiś czas Górny Śląsk pozostanie obszarem silnie zindustrializowanym, z czynnymi kopalniami podziemnymi. Można również założyć, że istniejące kopalnie będą podlegać przekształceniom - tak pod względem funkcjonalnym, jak i przestrzennym. Jest prawdopodobne, że w dłuższej perspektywie czasu część górnośląskich kopalni ulegnie likwidacji w procesie dostosowywania polskiego górnictwa węglowego do zmiennych realiów - zwłaszcza ekonomicznych, technicznych i prawnych.

\section{CZYNNE ZAKŁADY GÓRNICZE}

Działalność czynnych kopalni węgla rozpatrywana jest zazwyczaj przez pryzmat ich znaczenia gospodarczego, a także oddziaływania na środowisko. Istotne jest również krajobrazowe znaczenie kopalni podziemnych, a także ich rola społeczna i kulturowa. Przeprowadzone badania naukowe oraz niniejszy artykuł pomijają te zagadnienia, koncentrując się wyłącznie na aspektach funkcjonalnych. Jak wcześniej wspomniano, prawie cała produkcja polskiego węgla kamiennego opiera się na kopalniach górnośląskich - w regionie działa obecnie 17 kopalni podziemnych ${ }^{4}$, zarządzanych przez kilka różnych spółek skarbu państwa. W skład zespołów

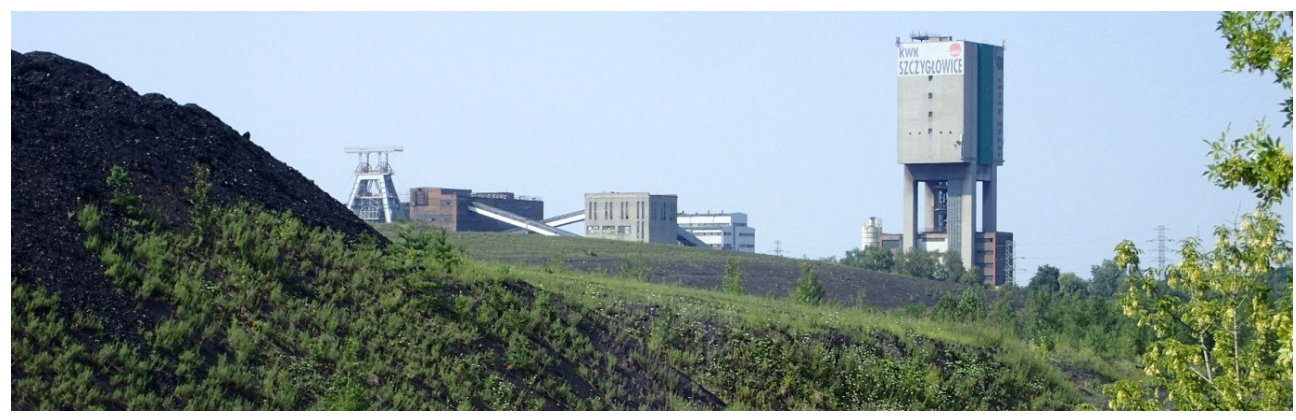

II. 3. Panorama nadszybia I-III kopalni węgla kamiennego „Knurów-Szczygłowice” - obiekty szybowe kopalni wyniesione ponad zbocze zwałowiska. Fot. autor, 2018

3 Obecnie należy do nich: Polska Grupa Górnicza, Węglokoks, Jastrzębska Spółka Węglowa, Tauron Wydobycie oraz kilka mniejszych podmiotów.

4 Są to kopalnie węgla kamiennego (KWK): „Bobrek-Piekary”, „Bolesław Śmiały”, „Borynia-Zofiówka”, „Budryk", ,Knurów-Szczygłowice”, „Murcki-Staszic”, „Mysłowice-Wesoła”, „Piast-Ziemowit”, „Pniówek”, „ROW”, „Ruda”, „Silesia” „Sośnica”, „Wujek” oraz zakłady górnicze (ZG): „Janina”, „Nowe Brzeszcze”, „Sobieski” (na podstawie danych publikowanych przez spółki węglowe). 
szybowych tych kopalni wchodzą przede wszystkim budynki szybów górniczych z charakterystycznymi wieżami wyciągowymi, zwałowiska, obiekty o funkcji administracyjnej, socjalnej, gospodarczej, magazynowej i technicznej, infrastruktura transportowa i komunikacyjna, obiekty związane z przeróbką węgla, odwadnianiem wyrobisk i utylizacją wód kopalnianych oraz wiele innych elementów, które łącznie składają się na funkcjonalną całość (il. 3).

\section{KOPALNIE PO ZAKOŃCZENIU DZIAŁALNOŚCI POPRZEMYSŁOWEJ}

Okres czynnej działalności przemysłowej każdej kopalni kończy się likwidacją zakładu górniczego. Proces ten jest regulowany prawem ${ }^{5}$ i obejmuje szerokie spektrum działań technicznych i organizacyjnych (Dz.U. 2011 nr 163 poz. 981). Przyczyny likwidacji zakładu górniczego mogą być złożone, a są to najczęściej: całkowita nierentowność lub niska opłacalność wydobycia kopalin (będąca głównie pochodną kosztów eksploatacji oraz ceny surowca), zmniejszająca się zasobność złóż, katastrofy górnicze lub realne zagrożenie takimi katastrofami, niszczący wpływ na środowisko. Konieczność reagowania na zmieniające się w czasie uwarunkowania powoduje, że wiele kopalni operujących w regionach czynnego górnictwa musi ulec likwidacji - w całości lub części ${ }^{6}$. Obecnie w fazie likwidacji zakładu górniczego znajdują się części dwóch kopalni górnośląskich - „Boże Dary” w kopalni „Murcki” (il. 4) oraz „Pułaski” w dawnej kopalni „Wieczorek”.

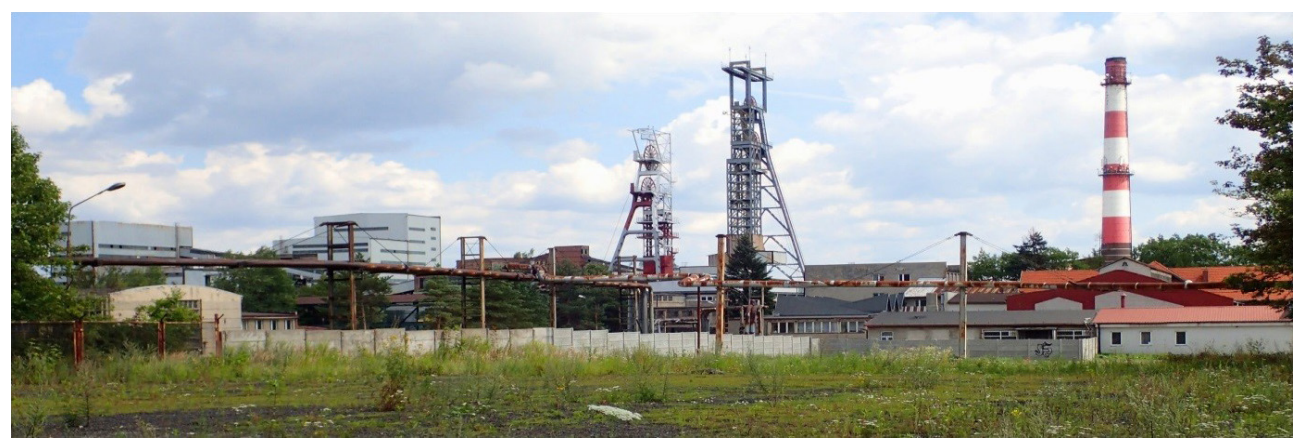

II. 4. Naziemna infrastruktura likwidowanego nadszybia „Boże Dary”, stanowiącego część kopalni „Murcki” w Katowicach. Fot. autor, 2018

5 Likwidację polskich zakładów górniczych reguluje ustawa Prawo geologiczne i górnicze (Dz.U. $2011 \mathrm{nr} 163$ poz. 981) wraz z powiązanymi aktami wykonawczymi.

6 Likwidacji 20 górnośląskich kopalni dokonano w ramach restrukturyzacji polskiego górnictwa węglowego prowadzonej na przełomie obecnego i ubiegłego stulecia na podstawie tzw. reformy Steinhoffa. Celem tej reformy była naprawa finansów kopalni, skutkiem zaś - ograniczenie wydobycia węgla o $21 \mathrm{~m} / \mathrm{n}$ ton rocznie oraz trwałe zwolnienie z pracy ponad 90 tys. górników. Reforma Steinhoffa była jak dotąd jedynym znaczącym i kompleksowym działaniem restrukturyzacyjnym w powojennej historii polskiego górnictwa węgla kamiennego (Money.pl, 2001). 


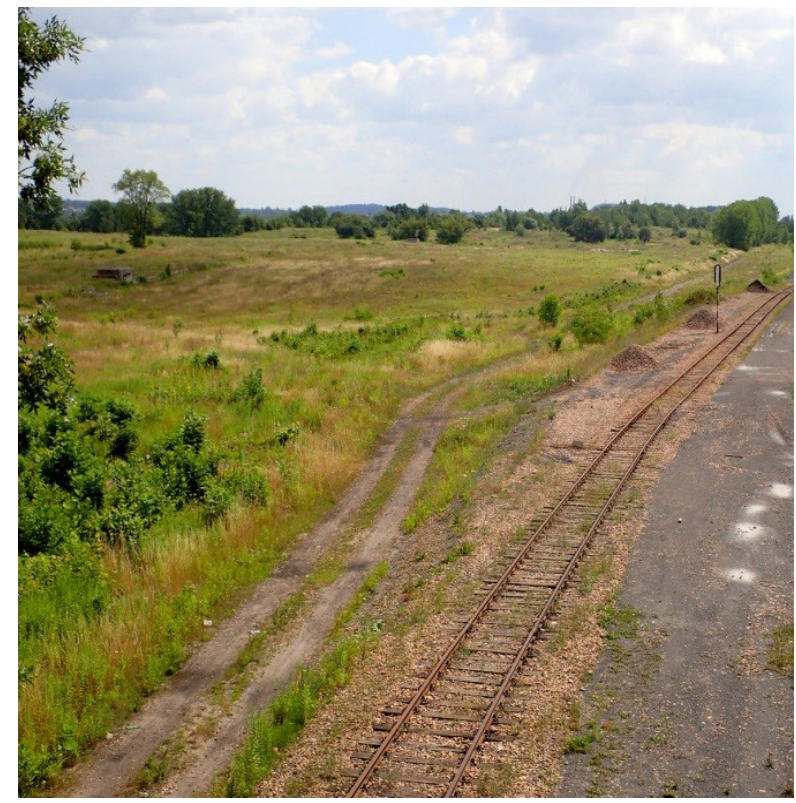

II. 5. Tereny po zlikwidowanej kopalni węgla kamiennego „Andaluzja” w Piekarach Śląskich. Fot. autor, 2018

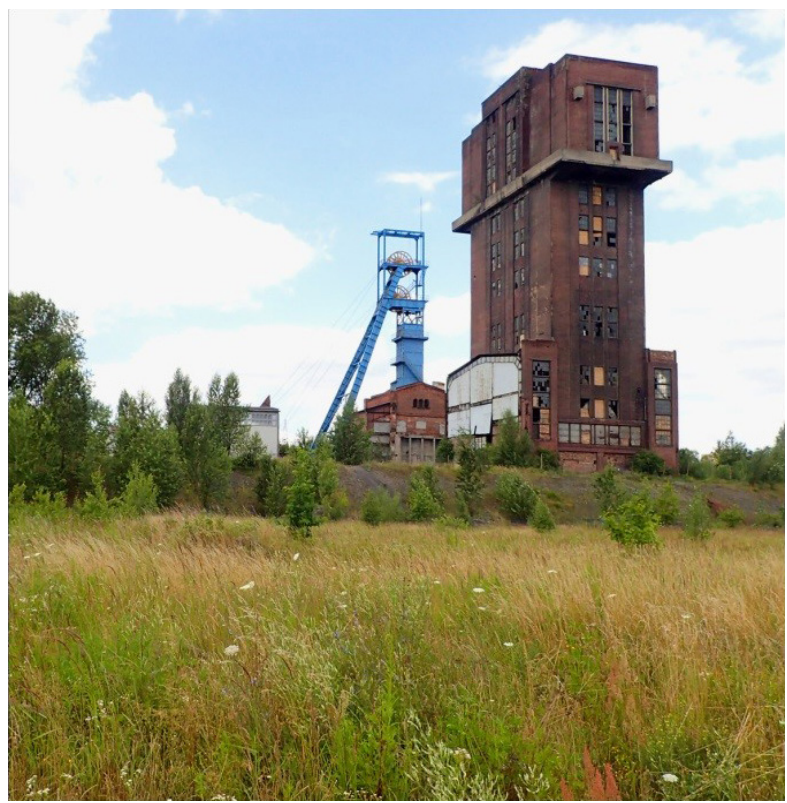

II. 6. Niszczejące relikty zabudowy szybowej i zachowana wieża wyciągowa kopalni „Szombierki” w Bytomiu. Fot. autor, 2018 
Prawo regulujące cele i zasady prowadzenia działań likwidacyjnych kładzie nacisk na nadrzędną potrzebę naprawy środowiska dotkniętego negatywnymi następstwami eksploatacji surowców, co skutkuje dążeniem do przywrócenia stanu środowiska sprzed rozpoczęcia eksploatacji górniczej. W praktyce likwidowanie kopalni podziemnej oznacza przeważnie fizyczne unicestwienie wszystkich lub prawie wszystkich obiektów pogórniczych, które stają się nieprzydatne do celów przemysłowych - zarówno wyrobisk podziemnych, jak i infrastruktury wydobywczej na powierzchni terenu. Jest to także podyktowane względami ekonomicznymi - „wyczyszczenie” i rekultywacja zdegradowanego obszaru pozwalają uniknąć dalszych kosztów utrzymywania nieczynnej kopalni, ułatwiają sprzedaż lub dzierżawę terenu i zapewniają swobodę w jego późniejszym zagospodarowaniu.

Skutkiem likwidacji kopalni może być trwałe lub czasowe przekształcenie terenu pogórniczego w nieużytek. Potwierdzają to przykłady kopalni „Wirek” w Rudzie Śląskiej, „Boże Dary” w Tychach oraz „Andaluzja” w Piekarach Śląskich (il. 5). Zdarza się, że w toku działań likwidacyjnych pozostawia się część lub tylko relikt zabudowy, w tym wieże wyciągowe, które trwają na terenach poeksploatacyjnych jako świadek dawnej funkcji. Tak jest w przypadku bytomskiej kopalni „Szombierki” (il. 6), kopalni „Dębieńsko” w Czerwionce-Leszczynach, „Kleofas” w Katowicach i wielu innych w całym regionie. Stan techniczny pozostawionych obiektów górniczych jest najczęściej zły, a nawet katastrofalny, co w znaczącym stopniu uniemożliwia ich ewentualne dalsze użytkowanie.

W niektórych przypadkach zachowuje się wybrane elementy, zakładając możliwość ich dalszego użytkowania po niezbędnej przebudowie. Zakres i charakter adaptacji zależą od bieżącego stanu zachowania oraz końcowego przeznaczenia likwidowanej kopalni, która docelowo może pełnić funkcje usługowe - zarówno publiczne, jak i komercyjne. Na przykładzie Górnego Śląska można wskazać dwa nurty funkcjonalnego przekształcania nieczynnych kopalni węgla kamiennego:

a. nurt komercyjny - adaptacja kopalni do prowadzenia działalności gospodarczej, najczęściej komercyjnej - niezwiązanej z dawną funkcją górniczą, bez eksponowania kulturowej wartości zachowanych obiektów oraz z umiarkowanym wykorzystaniem tej wartości;

b. nurt kulturowy - wtórne zagospodarowanie kopalni ukierunkowane na funkcje użyteczności publicznej powiązane z działalnością komercyjną, prowadzone z zamysłem wyeksponowania i celowego wykorzystania kulturowej wartości adaptowanych obiektów.

Należy podkreślić, że działania realizowane w obydwu nurtach mogą spełniać kryteria rewitalizacji terenów pogórniczych, tj. skutkować trwałym wyprowadzeniem obszaru ze stanu kryzysowego i przywróceniem jego witalności w sensie gospodarczym i społecznym. Istotna różnica pomiędzy powyższymi nurtami polega na sposobie podejścia do wartości kulturowej reprezentowanej przez zachowane elementy pogórnicze. W nurcie komercyjnym wartości te są traktowane przedmiotowo i nie decydują ani o kierunku, ani o sposobie zagospodarowania obiektów i terenów poeksploatacyjnych. Funkcje wprowadzane na obszary pogórnicze w ramach nurtu komercyjnego są raczej ukierunkowane na osiągnięcie zysków ekonomicznych 
i nie zawsze służą celom społecznym. Potwierdza to obecny stan nadszybia „Kolejowy l” chorzowskiej kopalni „Barbara”, które po likwidacji zakładu górniczego adaptowano na funkcję składową i magazynową, w tym złomowisko samochodów (il. 7). Za przykład działania w nurcie komercyjnym autor uznaje także zagospodarowanie dawnej kopalni „Gottwald” w Katowicach, którą w 2005 roku przekształcono na Silesia City Center (il. 8). Przebudowę prowadzono pod hasłem „rewitalizacji”, a samo centrum przyczyniło się do ożywienia terenu nieczynnej kopalni. Jednak przy adaptacji historycznego obiektu zniszczono lub zmarginalizowano szereg istotnych wartości, podporządkowując działania celom komercyjnym. W rezultacie powstało kolejne w regionie centrum handlowe, o dominującej skali urbanistycznej oraz dość pospolitej formie i estetyce. Pomimo zachowania i wykorzystania kilku oryginalnych elementów, historyczna zabudowa kopalni "Gottwald” uległa radykalnej transformacji, między innymi poprzez zaburzenie pierwotnego układu przestrzennego, rozbiórkę wielu nieprzydatnych budynków i przekształcenie zachowanej wieży szybowej na maszt reklamowy.

Dużą grupę górnośląskich kopalni węgla stanowią obiekty przebudowane i zagospodarowane w sposób zgodny z nurtem kulturowym - zazwyczaj przekształcone tak, aby spełniały funkcje użyteczności publicznej z zakresu turystyki, kultury, sztuki, muzealnictwa, rekreacji sportu i rozrywki, przy poszanowaniu i eksponowaniu zachowanych wartości. Zakres działań podejmowanych w tym nurcie jest jednak bardzo zróżnicowany. Zespół obiektów w Zabrzu - kopalnia węgla „Guido” (il. 9) ze sztolnią „Królowa Luiza” został po zakończeniu działalności przemysłowej zachowany wraz z częścią podziemnych wyrobisk górniczych i jest współcześnie wykorzystywany jako miejsce turystyczne. Obiekt ten należy do najważniejszych elementów górniczego dziedzictwa na Górnym Śląsku, a jego znaczenie kulturowe ma zasięg ponadregionalny ${ }^{7}$. Niektóre zlikwidowane kopalnie podziemne zostały poddane wybiórczej adaptacji, wykorzystano obiekty naziemne o szczególnym znaczeniu historycznym, architektonicznym i widokowym - z przeznaczeniem na funkcje publiczne. Zagospodarowanie takich kopalni obejmuje przebudowę istniejącej infrastruktury oraz wprowadzenie nowych, współczesnych elementów przy poszanowaniu zastanych wartości. Sztandarowym przykładem działań realizowanych w nurcie kulturowym jest przebudowa dawnej kopalni „Katowice" na nową siedzibę Muzeum Śląskiego, Narodowej Orkiestry Symfonicznej Polskiego Radia oraz Międzynarodowe Centrum Kongresowe wraz z licznymi funkcjami towarzyszącymi, także komercyjnymi (il. 10). Oprócz wymienionych można wskazać jeszcze inne przykłady podobnej metody adaptacji górnośląskich obiektów pogórniczych: kopalnię „Rozbark” w Bytomiu, szyb „Prezydent” w Chorzowie, kopalnię „Saturn” w Czeladzi, kopalnię „Gliwice” w Gliwicach, szyb „Wilson” kopalni „Wieczorek” w Katowicach, szyb „Krystyn” kopalni „Michał” w Siemianowicach Śląskich, części kopalni „Polska” w Świętochłowicach, a także szyb „Maciej” kopalni „Concordia” w Zabrzu.

7 O szczególnej randze tej kopalni świadczy jej obecny status: jest prawnie chronionym zabytkiem oraz punktem kotwicznym Europejskiego Szlaku Dziedzictwa Przemysłowego ERIH. Ponadto sztolnia „Królowa Luiza” została włączona do Szlaku Zabytków Techniki Województwa Śląskiego. 


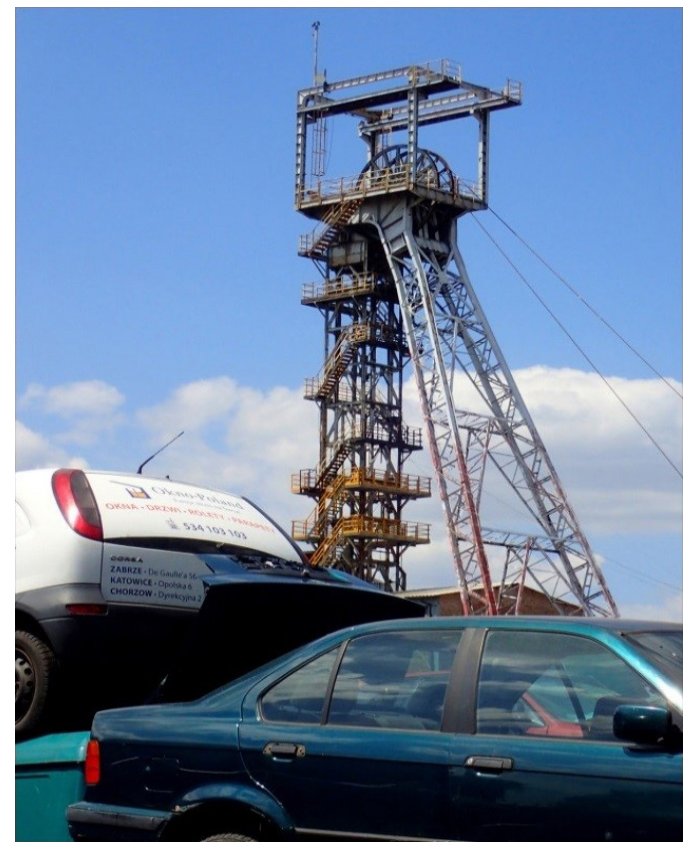

II. 7. Złomowisko samochodów na nadszybiu „Kolejowy I” kopalni „Barbara” w Chorzowie. Fot. autor, 2018

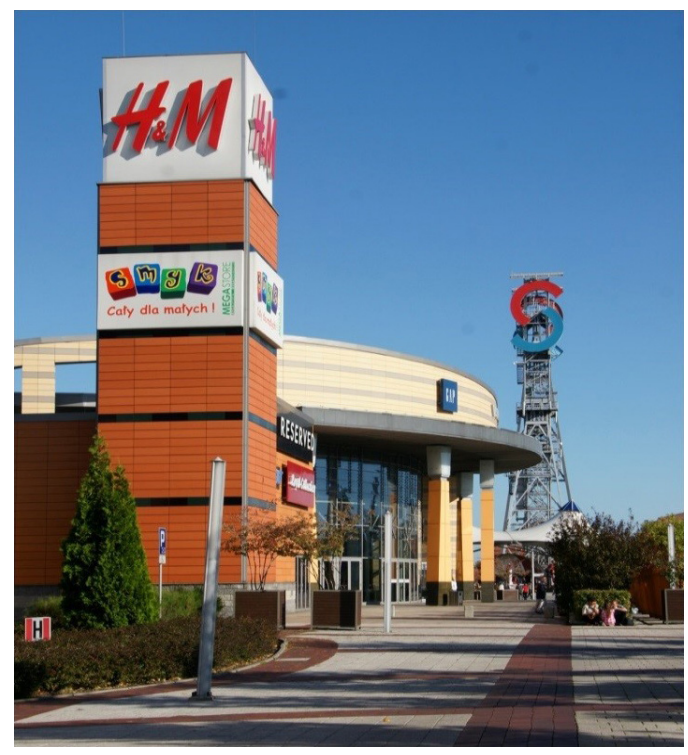

II. 8. Silesia City Center - współczesny obiekt handlowo-rozrywkowy wybudowany na terenie dawnej kopalni „Gottwald” w Katowicach - widok od strony głównego wejścia. Fot. autor, 2012 


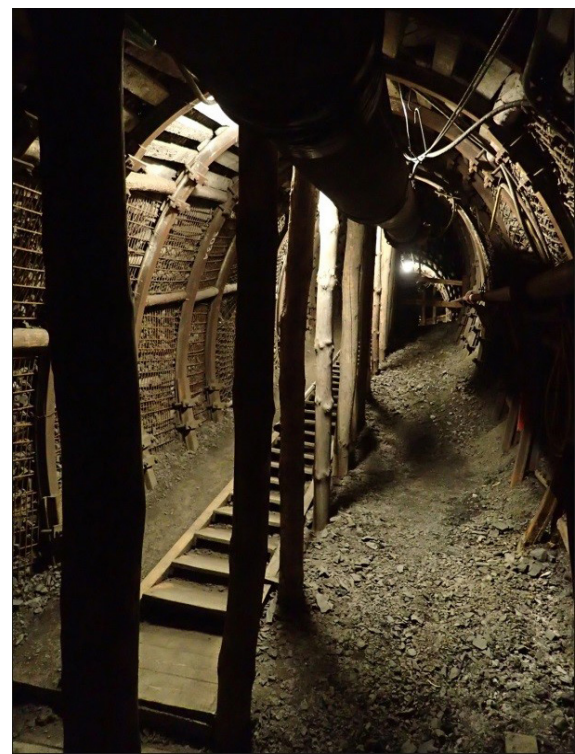

II. 9. Oryginalne wyrobiska górnicze na podziemnej trasie turystycznej w kopalni „Guido” w Zabrzu. Fot. autor, 2017

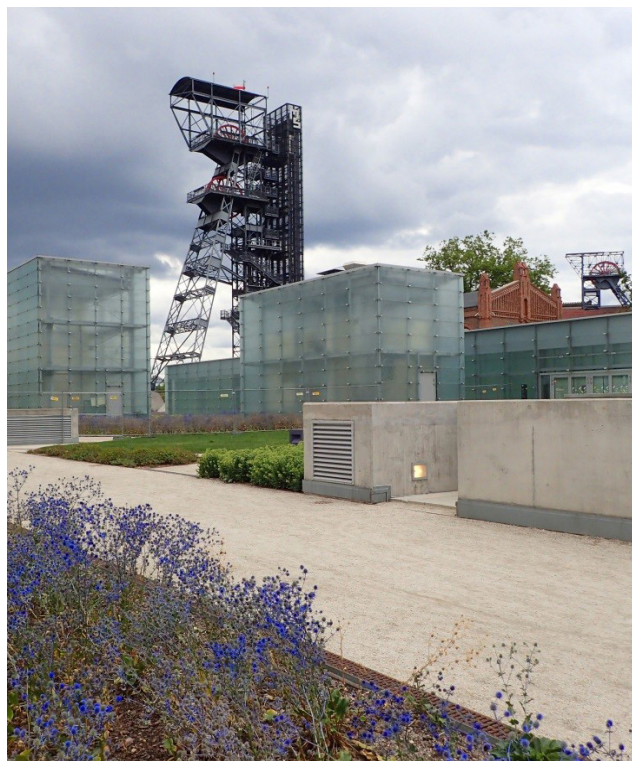

II. 10. Tereny kopalni „Katowice” zagospodarowane na wielofunkcyjny zespół obiektów użyteczności publicznej - widok na zachowane elementy zabudowy szybów „Bartosz” i „Warszawa”, otoczone współczesnymi obiektami architektonicznymi. Fot. autor, 2018 


\section{KOPALNIE PODZIEMNE REGIONU GÓRNOŚLĄSKIEGO - SYNTEZA WYNIKÓW BADAŃ}

Badaniami terenowymi objęto kilkadziesiąt miejsc związanych z eksploatacją węgla kamiennego metodą podziemną. Autor skupił się na rozpoznaniu obecnego stanu funkcjonowania oraz kierunku zagospodarowania i sposobu użytkowania zespołów szybowych w obrębie zlikwidowanych i czynnych kopalni. Przeanalizowano łącznie 38 wyodrębnionych miejsc na terenie 17 górnośląskich miast. Zrealizowane prace nie objęły wszystkich zespołów szybowych w regionie, jednakże grupę obiektów wytypowanych do badań można uznać za reprezentatywną - ze względu na liczebność, rozmieszczenie oraz zróżnicowanie cech, takich jak: aktualny stan działalności, czas i okres funkcjonowania jako obiekt przemysłowy, obecny stan zachowania wyrobisk górniczych i infrastruktury naziemnej, jak również kierunek zagospodarowania i forma użytkowania w okresie pogórniczym. Charakterystykę obiektów objętych badaniami terenowymi przedstawiono zbiorczo w tabeli (tab. 1).

Z danych zestawionych w tabeli wynika, że spośród wszystkich rozpatrywanych obiektów tylko 12 , czyli około 32\%, to zespoły szybowe czynnych zakładów górniczych. Dotyczy to zwłaszcza młodszych kopalni, które były budowane jeszcze w latach 70. ubiegłego wieku. Pozostałe 26 przebadanych obiektów to zespoły szybowe kopalni wyłączonych z czynnej działalności - już zlikwidowanych (24) lub aktualnie będących w likwidacji (2). Z zestawienia danych wynika, że czas intensywnej likwidacji górnośląskich kopalni przypada na ostatnią dekadę XX wieku oraz pierwsze lata obecnego stulecia. Zlikwidowano wtedy aż 16 analizowanych obiektów, co stanowi $42 \%$ wszystkich badanych i aż $62 \%$ w grupie nieczynnych. Zwraca uwagę fakt, że w rozpatrywanym okresie przeprowadzono likwidację zarówno najstarszych zakładów górniczych (np. kopalnia „Ignacy” w Rybniku - po 203 latach działalności wydobywczej), jak i tych młodszych (np. kopalnia „Barbara” w Bytomiu - zaledwie po 25 latach funkcjonowania). Wśród 24 kopalni podziemnych, których likwidacja została już zakończona, aż 9 (czyli prawie $40 \%)$ nie zostało adaptowanych do nowych funkcji - wszystkie stanowią obecnie nieużytek. W żadnej z tych kopalni nie zachowały się wyrobiska podziemne. Stan zachowania infrastruktury naziemnej w zlikwidowanych i nieużytkowanych kopalniach górnośląskich jest zróżnicowany. W przypadku niektórych kopalni („Andaluzja” w Piekarach Śląskich, „Wirek” w Rudzie Śląskiej, „Boże Dary” w Tychach) obiekty szybowe, w tym wieże wyciągowe, zostały całkowicie rozebrane, a tereny ich dawnej lokalizacji trudno nawet zidentyfikować ${ }^{8}$. W innych kopalniach infrastrukturę naziemną utrzymano częściowo lub wyłącznie w stopniu szczątkowym, jednak brak użytkowania i bieżącej konserwacji zachowanych obiektów skutkuje pogorszeniem ich stanu technicznego oraz ogranicza możliwość przyszłej adaptacji funkcjonalnej w nurcie kulturowym - między innymi z powodu postępującej degradacji oryginalnych wartości.

8 Wieżę wyciągową szybu „Czułów II” kopalni „Boże Dary” w Tychach zburzono 22 sierpnia 2018 roku, kilka dni po wykonaniu przez autora badań terenowych tego obiektu. 
Tab. 1. Zbiorcza charakterystyka obiektów górniczych - kopalni podziemnych i wyodrębnionych zespołów szybowych na terenie Górnego Śląska, objętych autorskimi badaniami terenowymi. Oprac. własne

\begin{tabular}{|c|c|c|c|c|c|c|c|}
\hline \multirow{2}{*}{ Lp. } & \multirow{2}{*}{ Miasto } & \multirow{2}{*}{$\underset{\text { (szyb/nadszybie })^{1}}{\frac{\text { Kopalnia }}{2}}$} & \multirow{2}{*}{$\begin{array}{l}\text { Obecny stan } \\
\text { działalności }\end{array}$} & \multirow{2}{*}{$\begin{array}{c}\text { Okres działalności } \\
\text { przemysłowej, } \\
\text { data } \\
\text { (liczba lat) }^{2}\end{array}$} & \multicolumn{2}{|c|}{ Obecny stan zachowania } & \multirow{2}{*}{$\begin{array}{l}\text { Obecna funkcja, } \\
\text { kierunek zagospodarowania } \\
\text { lub forma użytkowania }\end{array}$} \\
\hline & & & & & $\begin{array}{l}\text { Wyrobiska } \\
\text { górnicze }\end{array}$ & $\begin{array}{c}\text { Infrastruktura } \\
\text { naziemna }\end{array}$ & \\
\hline 1. & \multirow{2}{*}{ Bytom } & 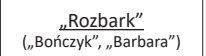 & घ & $\frac{1870-2004}{(134)}$ & - & - & siedziba teatru \\
\hline 2. & & $\frac{\text { („, Kzrombierki” }}{\text { Krystya”, „Ewa”) }}$ & - & $\frac{1870-1996}{(126)}$ & - & $\bullet$ & nieużytek \\
\hline 3. & \multirow{2}{*}{ Chorzów } & $\underset{(, \text { "Kolejowy I") }}{\text { (Barbara” }}$ & - & $\frac{1970-1995}{(25)}$ & - & - & składy i magazyny \\
\hline 4. & & $\underset{(, \text { „Prezydent”) }}{{ }^{\text {PPolska” }}}$ & [ & $\frac{1932-1975}{(43)}$ & - & - & $\begin{array}{l}\text { otwarte tereny parkowo-rekreacyjne } \\
\text { z zachowaną wieżą szybową }\end{array}$ \\
\hline 5. & Chudów & $\frac{\text { „Budryk” }}{(\text {,Chudów Vl”) }}$ & - & $\frac{\text { od } 1979}{(41)}$ & - & - & czynny zakład górniczy \\
\hline 6. & Czeladź & „Saturn” & घ & $\frac{1887-1996}{(109)}$ & - & - & galeria sztuki współczesnej \\
\hline 7. & $\begin{array}{l}\text { Czerwionka- } \\
\text {-Leszczyny }\end{array}$ & „Dębieńsko” & घ & $\frac{1853-2000}{(147)}$ & - & - & nieużytek \\
\hline 8. & \multirow{2}{*}{ Gliwice } & „Gliwice” & घ & $\frac{1901-2000}{(99)}$ & - & - & $\begin{array}{l}\text { siedziba Muzeum Odlewnictwa } \\
\text { Artystycznego oraz Centrum } \\
\text { Edukacji i Biznesu „Nowe Gliwice” }\end{array}$ \\
\hline 9. & & „Sośnica” & - & $\frac{\text { od } 1857}{(163)}$ & - & - & czynny zakład górniczy \\
\hline 10. & \multirow{8}{*}{ Katowice } & "Gottwald" & घ & $\frac{1904-2004}{(100)}$ & - & - & $\begin{array}{l}\text { centrum handlowo-usługowe Silesia } \\
\text { City Center }\end{array}$ \\
\hline 11. & & $\begin{array}{l}\text { („Bartosz", „Watowice” } \\
\text {,Warszawa”) }\end{array}$ & घ & $\frac{1823-1999}{(176)}$ & - & - & $\begin{array}{l}\text { siedziba Nowego Muzeum Śląskiego, } \\
\text { Narodowej Orkiestry Symfonicznej } \\
\text { Polskiego Radia i Międzynarodowego } \\
\text { Centrum Kongresowego }\end{array}$ \\
\hline 12. & & „Kleofas" & घ & $\frac{1845-2004}{(159)}$ & $\bullet$ & - & nieużytek \\
\hline 13. & & „Murcki-Staszic" & - & $\frac{\text { od } 1769}{(251)}$ & - & - & czynny zakład górniczy \\
\hline 14. & & $\left(\begin{array}{l}\text { „Murcki” } \\
(\text { Bozie Dary") }\end{array}\right.$ & - & $\frac{1902-2015}{(113)}$ & - & - & zakład górniczy w fazie likwidacji \\
\hline 15. & & „Wieczorek” & - & $\frac{1826-2018}{(192)}$ & - & - & zakład górniczy w fazie likwidacji \\
\hline 16. & & $\frac{{ }^{\prime} \text { Wieczorek” }}{(\text { „,Wilson”) }}$ & घ & $\frac{1826-2018}{(192)}$ & - & - & galeria sztuki współczesnej \\
\hline 17. & & 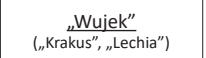 & घ & $\frac{\text { od } 1900}{(251)}$ & - & - & $\begin{array}{c}\text { czynny zakład górniczy, siedziba Izby } \\
\text { Pamięci Kopalni „Wujek” }\end{array}$ \\
\hline 18. & \multirow{3}{*}{ Knurów } & $\frac{\text { Knnurów-Szczygłowice }}{\left({ }^{\prime \prime} \text {,Foch l", ,Foch II") }\right.}$ & - & $\frac{1908-2005}{(97)}$ & - & - & nieużytek \\
\hline 19. & & $\frac{\text { Knurów-Szczzgłowice" }}{(\text {,Szyby I-III") }}$ & घ & $\frac{\text { od } 1957}{(63)}$ & - & - & czynny zakład górniczy \\
\hline 20. & & „Knurów-Szczygłowice” & - & $\frac{\text { od } 1973}{(47)}$ & - & - & $\begin{array}{l}\text { czynny zakład górniczy (szyb wen- } \\
\text { tylacyjny) }\end{array}$ \\
\hline
\end{tabular}




\begin{tabular}{|c|c|c|c|c|c|c|c|}
\hline 21. & \multirow{3}{*}{ Mysłowice } & $\frac{\text { „Mysłowice-Wesoła” }}{(\text { „Bończyk") }}$ & $\mathbf{\square}$ & $\frac{1911-1984}{(73)}$ & - & - & obiekt bankietowo-konferencyjny \\
\hline 22. & & $\frac{\text { "Mysłowice-Wesoła” }}{(\text { („Piotr”, „Bronisław”) }}$ & [ & $\frac{\text { od 1914 }}{(106)}$ & - & - & $\begin{array}{l}\text { czynny zakład górniczy, od } 2015 \\
\text { roku unieruchomiony }\end{array}$ \\
\hline 23. & & $\frac{{ }^{\text {Mysłowice-Wesoła” }}}{(, \text { Sas", ,tokietek") }}$ & - & $\frac{1837-2008}{(171)}$ & - & - & nieużytek \\
\hline 24. & Ornontowice & „Budryk” & - & $\frac{\text { od } 1979}{(41)}$ & - & - & czynny zakład górniczy \\
\hline 25. & \multirow{2}{*}{ Piekary Śląskie } & $\begin{array}{c}\text { „Andaluzja” } \\
\text { (,,Sienkiewicz”, } \\
\text { „Reymont”, ,,Zeromski”) }\end{array}$ & [ & $\frac{1911-1999}{(88)}$ & - & - & nieużytek \\
\hline 26. & & $\frac{\text { Bobrek-Piekary” }}{(, \text { Dołki”) }}$ & घ & $\frac{\text { od } 1907}{(113)}$ & - & - & czynny zakład górniczy \\
\hline 27. & \multirow{4}{*}{ Ruda Śląska } & 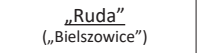 & घ & $\frac{\text { od } 1896}{(124)}$ & - & - & czynny zakład górniczy \\
\hline 28. & & $($ (,Halemaa”) & $\mathbf{\square}$ & $\frac{\text { od } 1957}{(63)}$ & - & $\bullet$ & czynny zakład górniczy \\
\hline 29. & & $\frac{\text { „Ruda" }}{(, \text {,Pokój”) }}$ & [ & $\frac{\text { od } 1902}{(118)}$ & - & - & czynny zakład górniczy \\
\hline 30. & & „Wirek" & - & $\frac{1849-1954}{(105)}$ & - & • & nieużytek \\
\hline 31. & Rybnik & $\begin{array}{l}\text { „Ignacy" } \\
\text { (,Gtowacki”, } \\
\text { „Kościuszko") }\end{array}$ & - & $\frac{1792-1995}{(203)}$ & - & - & skansen górniczy \\
\hline 32. & \multirow{2}{*}{$\begin{array}{l}\text { Siemianowice } \\
\text { Śląskie }\end{array}$} & $\frac{\text { SSiemianowice" }}{(\text {,Richter") }}$ & [ & $\frac{1945-1993}{(48)}$ & - & - & nieużytek \\
\hline 33. & & $\frac{\text { Michał” }}{(, \text { Krystyn") }}$ & [ & $\frac{1883-1994}{(111)}$ & - & - & $\begin{array}{c}\text { Siemianowickie Centrum Kultury } \\
\text { - Park Tradycji }\end{array}$ \\
\hline 34. & Świętochłowice & 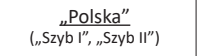 & - & $\frac{1872-2000}{(128)}$ & - & - & $\begin{array}{l}\text { komenda policji, wieża szybu I udo- } \\
\text { stępniona do zwiedzania }\end{array}$ \\
\hline 35. & Tychy & $\frac{\text { „Boże Dary” }}{(\text {, Czutów II") }}$ & $\mathbf{\square}$ & brak danych & - & $\bullet$ & nieużytek \\
\hline 36. & \multirow{3}{*}{ Zabrze } & $\frac{{ }_{\Perp} \text { Guido” }}{\text { (,„Szyb Kolejowy”) }}$ & - & $\frac{1855-1962}{(107)}$ & - & - & \multirow{2}{*}{$\begin{array}{l}\text { łącznie: siedziba Muzeum } \\
\text { Górnictwa Węglowego w Zabrzu, } \\
\text { podziemna trasa turystyczna }\end{array}$} \\
\hline 37. & & „Królowa Luiza” & $\mathbf{\square}$ & $\frac{1791-1998}{(207)}$ & - & - & \\
\hline 38. & & $\frac{\text { „Concordia” }}{(\text { „Maciej”) }}$ & 口 & $\frac{1841-1962}{(121)}$ & - & - & obiekt muzealny, gastronomia \\
\hline \multicolumn{4}{|c|}{ Obecny stan działalności kopalni/nadszybia: } & \multicolumn{4}{|c|}{ Obecny stan zachowania kopalni/nadszybia } \\
\hline [ & \multicolumn{3}{|c|}{$\begin{array}{l}\text { obiekt czynny, prowadzący działalność } \\
\text { wydobywczą }\end{array}$} & \multicolumn{4}{|c|}{ (wyrobiska górnicze i infrastruktura naziemna): } \\
\hline 口 & \multicolumn{3}{|c|}{ obiekt w fazie likwidacji } & \multicolumn{4}{|c|}{ - istniejące w całości } \\
\hline $\mathbf{\square}$ & \multicolumn{3}{|c|}{ obiekt zlikwidowany, nieużytkowany } & \multicolumn{4}{|c|}{ zachowane częściowo } \\
\hline घ & \multicolumn{3}{|c|}{$\begin{array}{l}\text { obiekt zlikwidowany, częściowo adaptowany } \\
\text { do nowej funkcji }\end{array}$} & \multicolumn{4}{|c|}{$\begin{array}{l}\text { - zachowane szczątkowo } \\
\text { - niezachowane (całkowicie zlikwidowane) }\end{array}$} \\
\hline
\end{tabular}

1 Nazewnictwo czynnych kopalni odpowiada obecnej strukturze organizacyjnej górnictwa węglowego na Górnym Śląsku, natomiast nazwy nieczynnych kopalni i szybów górniczych są zgodne z nazewnictwem historycznym z okresu likwidacji kopalni.

2 Na podstawie danych publikowanych w: Frużyński, 2012. 
W grupie kopalni zlikwidowanych aż 15 spośród 24 zostało adaptowanych do nowej funkcji, co stanowi ponad $60 \%$ nieczynnych kopalni i prawie $40 \%$ wszystkich badanych. W toku badań stwierdzono, że zakres i charakter przeprowadzonych działań adaptacyjnych wpisuje się w dwa odmienne nurty - komercyjny i kulturowy. Na podstawie analizy poszczególnych zespołów szybowych stwierdzono, że w regionie górnośląskim zdecydowanie przeważają obiekty adaptowane w nurcie kulturowym - stanowią aż 80\% kopalni, które po likwidacji zostały zagospodarowane i wykorzystane do nowych celów (12 z 15 obiektów). Wśród nich jest zespół górniczy: kopalnia węgla kamiennego „Guido” i sztolnia „Królowa Luiza” w Zabrzu, gdzie w celach użyteczności publicznej zachowano i udostępniono najbardziej wartościową część podziemnych wyrobisk. Podobnie jak w przypadku obiektów nieużytkowanych, kopalnie adaptowane różnią się pod względem stanu zachowania infrastruktury naziemnej. Kopalnia „Katowice”, przebudowana na wielofunkcyjny zespół obiektów użyteczności publicznej, jest przykładem kompleksowego zachowania i zagospodarowania budynków pogórniczych, w tym wież szybowych. Z kolei przykład szybu „Prezydent” dawnej kopalni „Polska” w Chorzowie pokazuje, że adaptacja w nurcie kulturowym może obejmować tylko wybrane elementy naziemne - w tym konkretnym przypadku zachowano jedynie wieżę wyciągową, wokół której urządzono niewielki park publiczny. Sama wieża została odpowiednio zabezpieczona i pełni funkcję punktu widokowego. Pozostałe 3 z 15 adaptowanych kopalni górnośląskich zaliczono ze względu na sposób i kierunek przeprowadzonych działań adaptacyjnych do nurtu komercyjnego. Są to: kopalnia „Barbara” w Chorzowie (obecnie teren składowo-magazynowy), kopalnia „Gottwald” w Katowicach (Silesia City Center) oraz szyb „Bończyk” kopalni „Mysłowice-Wesoła” w Mysłowicach (obecnie prywatny obiekt bankietowo-konferencyjny) ${ }^{9}$. Strukturę ilościową danych dotyczących górnośląskich kopalni obrazuje poniższa tabela (tab. 2).

Tab. 2. Struktura ilościowa danych dotyczących górnośląskich kopalni objętych badaniami autorskimi. Oprac. własne

\begin{tabular}{|c|c|c|c|c|c|c|c|c|}
\hline $\begin{array}{l}\text { Zasób } \\
\text { ogółem }\end{array}$ & $\begin{array}{l}w \\
\text { tym }\end{array}$ & $\begin{array}{c}\text { Stan } \\
\text { działalności } \\
\text { górniczej }\end{array}$ & $\begin{array}{l}w \\
\text { tym }\end{array}$ & Faza & $\begin{array}{l}w \\
\text { tym }\end{array}$ & $\begin{array}{c}\text { Stan } \\
\text { zagospodaro- } \\
\text { wania }\end{array}$ & $\begin{array}{l}w \\
\text { tym }\end{array}$ & $\begin{array}{l}\text { Nurt działań adap- } \\
\text { tacyjnych }\end{array}$ \\
\hline \multirow{5}{*}{$\begin{array}{l}\text { Łączna liczba } \\
\text { przebadanych } \\
\text { obiektów } \\
\text { (38) }\end{array}$} & \multirow{4}{*}{ 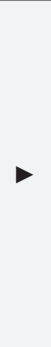 } & \multirow{4}{*}{$\begin{array}{l}\text { nieczynne } \\
\text { (26) }\end{array}$} & \multirow{3}{*}{$>$} & \multirow{3}{*}{$\begin{array}{l}\text { zlikwidowane } \\
\text { (24) }\end{array}$} & \multirow{2}{*}{$\triangleright$} & \multirow{2}{*}{$\begin{array}{c}\text { zagospodarowane } \\
\text { (15) }\end{array}$} & $>$ & $\begin{array}{l}\text { kulturowy } \\
\text { (12) }\end{array}$ \\
\hline & & & & & & & 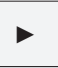 & $\begin{array}{l}\text { komercyjny } \\
\text { (3) }\end{array}$ \\
\hline & & & & & $>$ & $\begin{array}{l}\text { niezagospodaro- } \\
\text { wane } \\
\text { (nieużytki) } \\
\text { (9) }\end{array}$ & & \\
\hline & & & $>$ & $\begin{array}{l}\text { w toku } \\
\text { likwidacji } \\
\text { (2) }\end{array}$ & & & & \\
\hline & 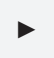 & $\begin{array}{l}\text { czynne } \\
\text { (12) }\end{array}$ & & & & & & \\
\hline
\end{tabular}

9 Kwalifikacja szybu „Bończyk” do nurtu komercyjnego nie jest całkowicie jednoznaczna. Obiekty pogórnicze pełnią funkcję czysto komercyjną, jednak istniejące wartości kulturowe tego obiektu są eksponowane oraz celowo wykorzystywane jako element specyfiki i atrakcyjności miejsca. 


\section{PODSUMOWANIE}

Autorskie badania objęły łącznie 38 miejsc związanych z eksploatacją węgla kamiennego - zespołów szybowych czynnych i nieaktywnych kopalni podziemnych. Z analizy wytypowanych przypadków wyłania się dość wyraźny obraz Górnego Śląska jako historycznego regionu górniczego, w którym można obserwować procesy i zjawiska typowe dla europejskich obszarów związanych z górnictwem węglowym. Są to w szczególności przemiany funkcjonalne, które towarzyszą fazie działalności przemysłowej zakładów wydobywczych, etapowi likwidacji kopalni podziemnych oraz ich transformacji i zagospodarowaniu w okresie pogórniczym. Na podstawie zebranych i zestawionych danych można stwierdzić, że zdecydowana większość górnośląskich kopalni to obiekty nieczynne (zlikwidowane lub pozostające w stanie likwidacji). Wśród nich, znacząca część (prawie 1/3 wszystkich badanych) została zagospodarowana i przystosowana do nowych funkcji w nurcie określonym przez autora jako kulturowy, tj. głównie do celów użyteczności publicznej, z zachowaniem i wykorzystaniem wartości historycznego dziedzictwa górniczego. Jednocześnie Górny śląsk jest jednym z ostatnich regionów europejskich, gdzie podziemne górnictwo węglowe pozostaje sektorem gospodarczym o wiodącym znaczeniu gospodarczym i społecznym. Pomimo spadku wielkości wydobycia węgla kamiennego w Polsce w regionie górnośląskim nadal działają kopalnie zatrudniające dziesiątki tysięcy górników. Są to miejsca trwania żywej kultury górniczej, aktywizujące lokalne społeczności do działania na rzecz ochrony, utrwalania i rozpowszechniania tej kultury.

Badania terenowe nad kopalniami Górnego śląska prowadzono równolegle z analogicznymi pracami w zachodnioeuropejskich regionach podziemnej eksploatacji węgla kamiennego - Zagłębiu Ruhry i Saary (Niemcy), Moselle i Nord-Pas-de-Calais (Francja), Limburgii (Belgia, Holandia). Na tle tych miejsc Górny Śląsk wykazuje się pewnymi podobieństwami, ale i zasadniczymi różnicami. Specyfika regionu górnośląskiego wynika wprost z obecnego stanu górnictwa węglowego, tj. aktywnej działalności przemysłowej kilkunastu kopalni podziemnych. Tymczasem wszystkie wymienione regiony Europy Zachodniej to obszary całkowicie pogórnicze, gdzie obecnie nie działa już żadna kopalnia węgla. Całkowita likwidacja górnictwa węgla kamiennego w państwach zachodnioeuropejskich była z pewnością uzasadniona względami gospodarczymi i przyczyniła się do poprawy jakości środowiska zniszczonego na skutek wydobywania surowca. Z drugiej jednak strony zamknięcie kopalni i ich późniejsza rozbiórka miały istotny wpływ na zmianę charakterystycznego krajobrazu przemysłowego, a także stopniowy zanik kultury górniczej, która jest nietrwała i ulotna, trudna do utrzymania w miejscach wyłączanych z czynnej działalności wydobywczej. Wydaje się zatem, że aktywne górnictwo węglowe na Górnym Śląsku sprzyja zachowaniu specyficznych dla tamtego obszaru wartości kulturowych - wciąż czytelnych w krajobrazie regionu i obecnych w życiu lokalnych społeczności.

Porównując Górny Śląsk do regionów węglowych w Zachodniej Europie, dostrzega się podobieństwo pomiędzy procesami charakterystycznymi dla fazy pogórniczej, obejmującej 
likwidację kopalni podziemnych oraz ich ewentualne zagospodarowanie. Należy w tym miejscu zastrzec, że Górny Śląsk i zachodnioeuropejskie regiony węglowe znajdują się w diametralnie różnej fazie tych procesów - co obecnie uniemożliwia przeprowadzenie ich szczegółowej analizy porównawczej. Ogólnie rzecz biorąc, we wszystkich regionach można wskazać obiekty poddane likwidacji całkowitej oraz takie, w których po definitywnym ustaniu działalności wydobywczej utrzymano określoną część obiektów naziemnych.

Wśród zachowanych kopalni niektóre pozostają nieużytkami, inne są przeznaczane na nowe funkcje - poprzez działania zgodne zarówno z nurtem komercyjnym, jak i kulturowym. W każdym zachodnioeuropejskim obszarze górnictwa węglowego istnieje przynajmniej jeden obiekt „flagowy” o ponadregionalnym znaczeniu kulturowym, adaptowany na cele użyteczności publicznej na podstawie zachownych wartości dziedzictwa pogórniczego. Są to między innymi: zespół kopalni i koksowni „Zollverein” w Essen i „Maximilianpark” w Hamm (Zagłębie Ruhry, Niemcy), kopalnia „Reden” w Schiffweiler (Zagłębie Saary, Niemcy), zespół górniczy „Petite-Rosselle” (Moselle, Francja), kopalnia „Dourges” w Oignies (Nord-Pas-de-Calais, Francja), kopalnia „C-Mine” w Genk oraz kopalnia w Beringen (Limburgia, Belgia). Także na Górnym Śląsku znajduje się obiekt pogórniczy o szczególnym znaczeniu, za który można uznać dawną kopalnię „Katowice”, współcześnie adaptowaną na siedzibę Muzeum Śląskiego, Narodowej Orkiestry Symfonicznej Polskiego Radia i Międzynarodowego Centrum Kongresowego. Porównując europejskie kopalnie przebudowane w nurcie kulturowym należy podkreślić, że tylko w kilku miejscach Zachodniej Europy podjęto decyzję o częściowym wykorzystaniu wyrobisk górniczych. W celach turystycznych udostępniono podziemną część kopalni „Delloye” w Lewarde (Nord-Pas-de-Calais, Francja) oraz kopalnię „Velsen” (Zagłębie Saary, Niemcy). W żadnej z kopalni na terenie Zagłębia Ruhry w Niemczech, francuskiego regionu Moselle czy belgijsko-holenderskiej Limburgii nie ma już dostępu do oryginalnych wyrobisk górniczych. W tym kontekście warto raz jeszcze wymienić zespół górniczy w Zabrzu, którego bieżąca działalność opiera się na podziemnej trasie turystycznej, wiodącej po najbardziej wartościowych wyrobiskach górniczych - zachowanych i eksponowanych w prawie niezmienionej formie.

\section{WNIOSKI}

Rozważając przyszłość Górnego Śląska, można przypuszczać, że niezależnie od bieżących deklaracji i działań politycznych prędzej czy później nastąpi regres, a nawet koniec polskiego górnictwa węglowego w jego dotychczasowej formie. Za takim scenariuszem przemawiają jednoznacznie doświadczenia większości krajów zachodnioeuropejskich oraz narastająca presja modernizacji sektorów polskiego przemysłu, istotnych dla czystości środowiska i ochrony klimatu - zwłaszcza w zakresie energetyki konwencjonalnej, korzystającej z węgla pozyskanego w kopalniach górnośląskich. Symptomem nieuniknionych zmian jest trwająca 
od trzech dekad transformacja górnictwa węglowego na Górnym Śląsku. Należy się spodziewać, że część obecnie czynnych kopalni zostanie za jakiś czas postawiona w stan likwidacji. Zrodzą się wtedy ważne pytania: czy po zakończeniu działalności przemysłowej zachowywać elementy pogórnicze, zwłaszcza nieczynne wyrobiska podziemne? Jeśli tak, to w jaki sposób je przekształcać i adaptować, by kreując nową przestrzeń chronić i eksponować zastane wartości? Znalezienie odpowiedzi na postawione pytania wydaje się być kluczowe nie tylko dla teraźniejszej transformacji górnośląskich kopalni podziemnych, ale również może ważyć na całej przyszłości Silesia Superior jako historycznego regionu pogórniczego.

\section{BIBLIOGRAFIA}

Alves Dias, P., Kanellopoulos, K., Medarac, H., Kapetaki, Z., Miranda-Barbosa, E., Shortall, R., Czako, V., Telsnig, T., Vazquez-Hernandez, C., Lacal Arántegui, R., Nijs, W., Gonzalez Aparicio, I., Trombetti, M., Mandras, G., Peteves, E., Tzimas, E. (2019). EU coal regions: opportunities and challenges ahead - JCR Science for Policy Report. Luxembourg: Publications Office for European Union.

Chmielewska, M. (2010). Kopalnie węgla kamiennego w Katowicach. Dzieje górnictwa-element europejskiego dziedzictwa kultury, 3, 50-59.

Frużyński, A. (2012). Kopalnie węgla kamiennego w Polsce. Łódź: Dom Wydawniczy Księży Młyn.

Gawlik, L. (red.). (2013). Węgiel dla polskiej energetyki w perspektywie 2050 roku - analizy scenariuszowe. Katowice: Górnicza Izba Przemysłowo-Handlowa.

Gawlik, L., Lorenz, U. (2014). Ile węgla kamiennego dla energetyki? Polityka Energetyczna - Energy Policy Journal, 17(3), 19-32.

Główny Urząd Statystyczny. (2017). Zużycie paliw i nośników energii w 2016 r. Warszawa.

Jelinek, M. (2013). Coal - an enabling component of energy systems evolution. Bruksela: European Parliament.

Kaliski, M., Sikora, A., Szurlej, A. (2014). Węgiel kamienny w polityce energetycznej Polski. Polityka Energetyczna - Energy Policy Journal, 17(3), 7-18.

Kaźmierczak, U., Lorenc, M., Strzałkowski, P. (2017). The analysis of the existing terminology related to a post-mining land use: a proposal for new classification. Environmental Earth Sciences, 76(20), 693, 1-10.

Kuter, N. (2013). Reclamation to Degraded Landscapes due to Opencast Mining. W: M. Özyavuz (red.), Advances in Landscape Architecture (s. 823-858). IntechOpen.

Langer, P. (2017). Life and death of a colliery. The condition and significance of former coal mining facilities in the transborder region of Saarland-Moselle. Technical Transactions, 9(114), 23-42.

Langer, P. (2019). "Post-mining reality" in western Europe: selected collieries in Belgium and France following discontinuation of coal mining. IOP Conference Series: Material Science and Engineerieng, (471), 1-10. 
Ministerstwo Gospodarki. (2018). Program dla sektora górnictwa węglowego w Polsce. Warszawa.

Money.pl. (2001). Reforma górnictwa największym osiqggnięciem rzq̨u. Pobrane z: www. money.pl (dostęp: 02.06.2020).

Podgórska-Jurkowska, P. (1994). Górnictwo węglowe w województwie katowickim. Katowice: Wojewódzki Urząd Statystyczny.

Probierz, K. (2015). Górnictwo węgla kamiennego w Polsce u progu 2015 roku, szanse i zagrożenia. Przeglq̨d Górniczy, 4, 22-37.

Stala-Szlugaj, K., Grudziński, Z. (2017). Import oraz eksport węgla kamiennego i ich wpływ na zapotrzebowanie energetyki zawodowej w Polsce. Journal of the Polish Mineral Engineering Society, lipiec-grudzień, 313-320.

Stala-Szlugaj, K. (2014). Import węgla kamiennego do Polski. Przegląd Górniczy, 5, 32-38.

Ustawa z dnia 9 czerwca 2011 r. Prawo geologiczne i górnicze (Dz.U. 2011 Nr 163 poz. 981). Wehnert,T., Bierwirth, A., Buschka, M., Hermwille, L., Mersmann, L. (2017). Phasing-out Coal, Reinventing European Regions. An analysis of EU Structural Funding in four European Coal Regions. Wuppertal and Berlin: Wuppertal Institute for Climate, Environment and Energy. 